Прегледни чланак

339.923:061.1EEU(497.11)

doi:10.5937/zrpfns51-14472

Daniel Haitas, Teaching Fellow and Ph.D. Student

University of Debrecen

Faculty of Law

Géza Marton Doctoral School of Legal Studies

danielhaitas@gmail.com

\title{
AN OVERVIEW OF THE EURASIAN ECONOMIC UNION AND ITS RELATIONSHIP WITH SERBIA ${ }^{1}$
}

Abstract: In addition to the European Union, other regional integration projects have arisen in different parts of the world. One prominent example of this is the Eurasian Economic Union (EAEU), which seeks to reintegrate the former Soviet space. It includes among its members Armenia, Belarus, Kazakhstan, Kyrgyzstan, and Russia. To a certain extent the EAEU draws inspiration from the European Union, seeing it as model it can emulate and from which it can learn, where appropriate. The EAEU is open to new members and also seeks partners, including in Europe. An example of this is Serbia, which has expressed interest in signing a free trade agreement with EAEU. From a purely legal point of view, this may be possible, as it is not prohibited by Serbia's SAA. However, such a development may also have its problematic aspects, which includes Serbia's obligations if it becomes a fully-fledged member of the European Union and the nature of the Common Commercial Policy (CCP).

Keywords: Regional Integration, Eurasian Economic Union, European Union, Serbia, Free Trade Agreement.

\section{INTRODUCTION}

The phenomenon of regionalization can be said to be one of defining and vital characteristics of international relations in the modern era. ${ }^{2}$ The European Union has been perhaps the greatest example of a supranational regional integra-

\footnotetext{
${ }^{1}$ The paper was created within the framework of programmes aiming the increasing of quality of lawyer education (IX - 14/6/2/2017. contract number) (Ministry of Justice, Hungary).

${ }^{2}$ Zhenis Kembayev, "Regional Integration in Eurasia: The Legal and Political Framework", Review of Central and East European Law, 41/2016, 158.
} 
tion process in modern times. It has seen a vast area of continental Europe come together and create common institutions, laws, structures, borders, courts, and so on. The model of the EU has served as an inspiration for other such projects around the world, such as the Eurasian Economic Union (EAEU), which came into being in 2015. It has been explicitly stated and repeated that the EAEU seeks, to a certain extent, to emulate the EU in the post-Soviet space, claiming to learn from the successes and mistakes of the latter. The EAEU can then be seen as a parallel structure literally being created and formed on the borders of the European Union, which purports to mirror it in certain aspects. Here there shall be a survey of the background to the formation of the Eurasian Economic Union, as well as an overview of its institutional and legal structure. In addition, Serbia's relations to the EAEU shall also be examined. Due to various historical, cultural and geopolitical factors, Serbia, despite its push towards European Union integration, has strong connections to the states to the East of the EU, particularly Russia. These connections manifest themselves in various ways, one of which is the attempt to pursue a multi-vector foreign policy, which includes seeking to establish a meaningful and tangible relationship with the EAEU. The article shall attempt to examine the basic contours and aims of this relationship, and the realistic possibilities for its deepening and expansion in the context of Serbia's EU candidate status and membership aspirations.

\section{BACKGROUND TO THE FORMATION OF THE EURASIAN ECONOMIC UNION}

With the collapse of the Soviet Union, a single, deeply integrated economic, political and institutional legal space was separated into 16 different states. ${ }^{3}$ Prior to the creation of the Eurasian Economic Union there had been various attempts at forming international organizations in order to reintegrate this post-Soviet space, the first being the Commonwealth of Independent States. ${ }^{4}$ The CIS, though helping to maintain certain links between former Soviet territories, through such mechanisms as the mobility of labour and visa-free travel, was unable to put forward a clear project for an integrated political and economic community. ${ }^{5}$ It is generally acknowledged that the modern thrust towards Eurasian ${ }^{6}$ integration

${ }^{3}$ Canan Atligan, et. al., "The Eurasian Union: An Integration Project Under the Microscope", Konrad Adenauer Stiftung International Reports, 2/2014, 8, http://www.kas.de/wf/doc/kas_36785544-2-30.pdf?140207134233, 10 June 2017.

${ }^{4}$ Ibid.

${ }^{5}$ Richard Sakwa, "Eurasian Integration: A Project for the 21st Century", The Eurasian Project and Europe: Regional Discontinuities and Geopolitics (eds. David Lane and Vsevolod Samokhalov), Hampshire, 2015.

${ }^{6}$ The terms "Eurasia" itself is open to different interpretations and definitions, based on different geopolitical preconceptions. Speaking in terms of purely physical geography, it may be 
began with a speech made in 1994 by Kazakh President Nursultan Nazarbayev at the Lomonosov Moscow State University. ${ }^{7}$ Following this, in 1995 the Russian Federation, Belarus and Kazakhstan signed an Agreement on the Customs Union, the aim of which was to remove trading barriers and encourage the economic integration of these states. ${ }^{8}$ Later came the Eurasian Economic Community, formed in 2000 by Belarus, Kazakhstan, Kyrgyzstan, Russia, Tajikistan and Uzbekistan, the aim of which was promote the creation of a single economic space and customs union among these signatory states. ${ }^{9}$ Next, The Eurasian Customs Union was formed in 2010, its original members being Belarus, Kazakhstan and Russia, with it at the time being seeing as the foundation stone for a future "Eurasian Union." 10 After, the Single Economic Space or Eurasian Economic space came into being in $2012 .{ }^{11}$

It is undeniable that Russia has provided the main impetus and force behind attempts to reintegrate the post-Soviet space..$^{12}$ Russian President Vladimir Putin himself has described the collapse of the Soviet Union as "the biggest geopolitical catastrophe of the century". ${ }^{13}$ In 2011, President Putin published an article in Izvestia where he set out his vision for a Eurasian Union. Drawing explicitly from the example of the European Union, he stated that "It took Europe 40 years to move from the European Coal and Steel Community to the full European Union. The establishment of the Customs Union and the Common Economic Space is proceeding at a much faster pace because we could draw on the experience of the EU and other regional associations. We see their strengths and weaknesses. And

defined as the landmass between the Atlantic and the Pacific oceans. In terms of geopolitics, it usually refers to the lands of the former Soviet Union, excluding the three Baltic states. See Kadri Liik, Introduction: Russia's pivot to (Eur)asia, Russia's Pivot to Eurasia, European Council on Foreign Relations, 2014, 6, http://www.ecfr.eu/page/-/ECFR103_RUSSIA_COLLECTION_290514_ AW.pdf, 10 June 2017.

${ }^{7}$ Eurasian Economic Commission, Eurasian Economic Integration: Facts and Figures, 2015, 6, http://www.eurasiancommission.org/en/Documents/broshura26_ENGL_2014.pdf, 11 June 2017.

${ }^{8}$ Ibid.

${ }^{9}$ Georgios L. Vousinas, "Eurasian Economic Community: Towards Integration. Economic Challenges and Geostrategic Aspects", Modern Economy, 5/2014, 951, http://dx.doi.org/10.4236/ me.2014.59088, 12 June 2017.

${ }^{10}$ Iana Dreyer and Nicu Popescu, The Eurasian Customs Union: The economics and the politics, European Union Institute for Security Studies: Brief Issue, March 2014, 1, http://www. iss.europa.eu/uploads/media/Brief_11_Eurasian_Union.pdf, 12 June 2017.

${ }^{11}$ Rilka Dragneva and Kataryna Wolczuk, The Eurasian Economic Union: Deals, Rules and the Exercise of Power, Chatham House, May 2017, 4, https://www.chathamhouse.org/sites/files/ chathamhouse/publications/research/2017-05-02-eurasian-economic-union-dragneva-wolczuk. pdf, 13 June 2017.

12 Zhenis Kemayev, "The Court of the Eurasian Economic Union: An Adequate Body for Facilitating Eurasian Integration?", Review of Central and Eastern European Law, 41/2016, 343.

${ }^{13}$ Claire Bigg, Was Soviet Collapse Last Century's Worst Geopolitical Catastrophe?, April 29 2005, RadioFreeEurope Radio Liberty, http://www.rferl.org/a/1058688.html 20 June 2017. 
this is our obvious advantage since it means we are in a position to avoid mistakes and unnecessary bureaucratic superstructures."14 Furthermore, drawing again from the example of the EU, he stated that, "In fact, we are adapting the experience of the Schengen Agreement that benefits Europeans as well as everyone who comes to work, study, or holiday in the EU." 15 Furthermore, in Putin's stated vision of Eurasian Union, the creation of such a union is seen as a stepping stone for a greater integration project with the European Union, “...take the two largest associations on our continent - the European Union and the Eurasian Union currently under construction. In building cooperation on the principles of free trade rules and compatible regulation systems they are in a position to disseminate these principles, including through third parties and regional institutions, all the way from the Atlantic to the Pacific Oceans. They will thus create an area that will be economically harmonised, but that still will remain diverse when it comes to specific mechanisms and management solutions." 16

On May 292014 the Treaty on the Eurasian Economic Union was signed in Kazakhstan, and on January 12015 it came into force. ${ }^{17}$ Upon the signing of the Treaty, President Putin declared that "Today we are creating a powerful, attractive center of economic development, a big regional market that unites more than 170 million people." 18 The member states of the EAEU now include the Republic of Armenia, the Republic of Belarus, the Republic of Kazakhstan, the Kyrgyz Republic, and the Russian Federation. ${ }^{19}$

\section{STRUCTURE AND INSTITUTIONS OF THE EURASIAN ECONOMIC UNION}

The Preamble of the Treaty on the Eurasian Economic Union sets out the guiding principles of the organization and itsraison d'être, and it is justified to quote it at length. ${ }^{20}$ It states that, "guided by the principle of the sovereign equality of states, the need for unconditional respect for the rule of constitutional rights

14 Vladimir Putin, "A new integration project for Eurasia: The future in the making”, Izvestia, October 4 2011, http://www.europarl.europa.eu/meetdocs/2009_2014/documents/d-ru/dv/ dru_2013_0320_06_/dru_2013_0320_06_en.pdf, 20 June 2017.

${ }^{15} \mathrm{Ibid}$.

${ }^{16}$ Ibid

${ }^{17}$ R. Dragneva and K. Wolczuk, 4.

${ }^{18}$ Neil Macfarquhar, "Russia and 2 Neighbors Form Economic Union That Has a Ukraine-Size Hole", The New York Times, May 29 2014, https://www.nytimes.com/2014/05/30/world/europe/ putin-signs-economic-alliance-with-presidents-of-kazakhstan-and-belarus.html?_r=1, 25 June 2017.

${ }^{19}$ Eurasian Economic Union, General Information, http://www.eaeunion.org/?lang=en\#about.

${ }^{20}$ Treaty on the Eurasian Economic Union (Courtesy Translation), http://www.un.org/en/ga/ sixth/70/docs/treaty_on_eeu.pdf, 20 June 2017. 
and freedoms of man and national, seeking to strengthen the solidarity and cooperation between their peoples while respecting their history, culture and traditions, convinced that further development of Eurasian economic integration shall serve the national interests of the Parties, driven by the urge to strengthen the economies of the Member States of the Eurasian Economic Union and to ensure their balanced development, convergence, steady growth in business activity, balanced trade and fair competition, ensuring economic progress through joint actions aimed at solving common problems faced by the Member States of the Eurasian Economic Union with regard to sustainable economic development, comprehensive modernisation and improving competitiveness of national economies within the framework of the global economy, confirming their commitment to further strengthen mutually beneficial and equal economic cooperation with other countries, international integration associations, and other international organisations, taking into account the regulations, rules and principles of the World Trade Organisation, confirming their commitment to the objectives and principles of the United Nations Charter and other universally recognised principles and regulations of international law,..."

Furthermore, Part 1, Section 1, Article 1.1-2 of the Treaty states that "The Parties hereby establish the Eurasian Economic Union ... ensuring free movement of goods, services, capital and labour within its borders, as well as coordinated, agreed or common policy in the economic sectors determined under this Treaty and international treaties within the Union" and that "The Union shall be an international organisation of regional economic integration and shall have international legal personality".

With regards to the Customs Union formed by the EAEU member states, Section VI sets out its "Principles of Functioning". Article 25 states that "1. Within the Customs Union of the Member States: 1) an internal market for goods shall be in place; 2) the Common Customs Tariff of the Eurasian Economic Union and other common measures regulating foreign trade with third parties shall be applied; 3) a common trade regime shall be applied to relations with third parties; 4) Common customs regulations shall be applied; 5) free movement of goods between the territories of the Member States shall be ensured without the use of customs declarations and state control (transport, sanitary, veterinary-sanitary, phytosanitary quarantine), except as provided for by this Treaty."

Section III, Article 8 of the Treaty sets out Bodies of the Union, which include the Supreme Eurasian Economic Council, the Eurasian Intergovernmental Council, the Eurasian Economic Commission and the Court of the Eurasian Economic Union.

Article 10.1-2 of the Treaty state that "The Supreme Council shall be the supreme Body of the Union" and that "The Supreme Council shall consist of the heads of the Member States." According to Article 11.1, "Meetings of the Supreme Council shall be held at least once a year." Article 12.1 states that "The Supreme Council shall consider the main issues of the Union's activities, define the strategy, 
directions and prospects of the integration development and make decisions aimed at implementing the objectives of the Union." According to Article 13.2, Decisions and dispositions of the Supreme Council shall be adopted by consensus." This principle is said to be an acknowledgement of the sensibilities of certain member states, who wish to safeguard their national sovereignty. ${ }^{21}$ This concern even extends to the choice of the name "Eurasian Economic Union", which reflects the conception of the organization according to certain member states. Kazakhstan's first deputy prime minister and chief negotiator BakytzhanSagintayev stated that "We are not creating a political organization; we are forming a purely economic union ... It is a pragmatic means to get benefits. We don't meddle into what Russia is doing politically, and they cannot tell us what foreign policy to pursue."'22

Article 14 states that "The Intergovernmental Council shall be a Body of the Union consisting of the heads of governments of the Member States." According to Article 15.1, "Meetings of the Intergovernmental Council shall be held as necessary, but at least twice year." Its responsibilities include, among others, ensuring implementation and control of the Treaty, as well as "international treaties within the Union and decisions of the Supreme Council"23. Additionally, the Intergovernmental Council can "consider, on the proposal of the Council of the Commission, any issues for which no consensus was reached during decision-making in the Council of the Commission." ${ }^{24}$

Articles 18.1-2 state that "The Commission shall be a permanent governing Body of the Union. The Commission shall consist of a Council and a Board" and that "The Commission shall issue decisions, dispositions and recommendations." Annex I to the Treaty states that "The basic objectives of the Commission shall be to enable the functioning and development of the Union, as well as to develop proposals in the sphere of economic integration within the Union." ${ }^{25}$ According to the Treaty, the residence of the Commission is to be in Moscow. ${ }^{26}$

According to the Treaty, in the case of conflict between the various above mentioned institutions, the Supreme Economic Council decisions prevail over those of the Intergovernmental Council and Economic Commission, while the Intergovernmental Council's decisions prevail over those of the Economic Commission. ${ }^{27}$

With regards to the Court of the Union, Article 19.1 declares that "The Court of the Union shall be a permanent judicial Body of the Union". According Chap-

${ }^{21}$ Madalina Vicari, "The Eurasian Economic Union- approaching the economic integration in the post-Soviet space by EU-emulated elements", Papers in Political Economy, 55/2016, https:// interventionseconomiques.revues.org/2823, 26 June

${ }^{22} \mathrm{~N}$. Macfarquhar.

${ }^{23}$ Art. 16.1 .

${ }^{24}$ Art. 16.2.

${ }^{25}$ Chap. 1.1.

${ }^{26}$ Art. 18.4.

${ }^{27}$ Art. 6.4. 
ter 1.2 of the Annex 2 to the Treaty on the Eurasian Economic Union, "The objective of the Court's activities shall be to ensure, in accordance with the provisions of this Statute, uniform application by the Member States and Bodies of the Union of the Treaty, international treaties within the Union, international treaties of the Union with a third party and decisions of the Bodies of the Union." Chapter 2.7-8 of the Annex 2 state the Court shall be composed of two judges from each of the respective Member States, each serving a term of 9 years. According to Chapter 2.10, "Judges shall be appointed by the Supreme Eurasian Economic Council on the proposal of the Member States." It began its operation on January $12015^{28}$ and, in accordance with Article 19.3 of the Treaty, is located in Minsk, Belarus.

According to Article 110.1 of the Treaty, the "Russian language shall be the working language of the Bodies of the Union" and Article 110.2 states that "International treaties within the Union and decisions of the Commission that are binding on the Member States shall be adopted in Russian."

\section{SERBIA AND THE EURASIAN ECONOMIC UNION}

The EAEU, like the European Union, being a multi-national international organization, is both open to new members and seeks to broaden its relations and contacts with various states throughout the world. One prominent example of this in Europe is Serbia. Despite being having the status of a candidate country for European Union membership, Serbia is firmly pursuing what may be termed as a multi-vector foreign policy, one which seeks to maintain a diverse array of friendly relations with countries that are not Member States of the EU or part of the broader Euro-Atlantic structures. A statement made by President Aleksandar Vucic at the Astana Expo 2017 clearly expresses this approach: "I think that Serbia is building a new image and a new face toward the world, not only the West, but also her in the East. I believe that our country, which has just over seven million people, which is territorially very small ... managed to occupy a very high position due to our policy of preserving independence and sovereignty and independent decision-making in foreign policy action and address." 29

One major component of this policy is Serbia's relationship with Russia, and, by extension, its desire to foster and deepen ties with the Eurasian Economic Union. This interest in cooperation with the bloc has even been publicly acknowledged by President Putin himself, who stated that work is being done in order to progress in this direction. ${ }^{30}$ The most concrete manifestation of this is the stated

${ }^{28}$ Eurasian Economic Union, Court of the Eurasian Economic Union, http://courteurasian.org/en/.

${ }^{29}$ B92, Serbia "building new image toward West and East", June 9 2017, http://www.b92. net/eng/news/politics.php?yyyy=2017\&mm=06\&dd=09\&nav_id=101509, 29 June 2017.

${ }^{30}$ B92, Serbia among countries interested in Eurasian Union - Putin, May 15 2017, http:// www.b92.net/eng/news/world.php?yyyy=2017\&mm=05\&dd=15\&nav_id=101271, 1 July 2017. 
goal of a free trade agreement between Serbia and the EAEU. ${ }^{31}$ The arguments for such an agreement include that it would further strengthen and solidify Serbia's presence in the Russian, Kazakh and Belarussian markets, while also opening markets such as Kyrgyzstan and Armenia. ${ }^{32}$ Serbian Foreign Minister Ivica Dacic said "We have free trade zone agreements with certain EAEU members but they differ in between. Now it is planned to develop and sign an integrated agreement between Serbia and the Eurasian Economic Union, that is, to perform certain unification of all these agreements. ${ }^{33}$ According to Rasim Ljajic, Minister of Trade, Tourism and Telecommunications, Serbia has a particular interest in expanding liberalization with EAEU economies in the area of different types of cotton, cheese, tobacco, sugar, poultry, wine and Fiat automobiles. ${ }^{34}$ It has also been argued that through a closer relationship with the EAEU Serbia could gain great access to Asian economies, and that there could even be opportunities as a result of cooperation with the Eurasian Development Bank. ${ }^{35}$

The Stabilization and Association agreement signed between the European Union and Serbia states that "This Agreement shall not preclude the maintenance or establishment of customs unions, free trade areas or arrangements for frontier trade except in so far as they alter the trade arrangements provided for in this Agreement." 36 In June 2016 Maja Kocijancic, European Union spokesperson for foreign and security policy, made the statement that "We have taken note that the EEU is starting negotiation with Serbia. It is clear to us that presently Serbia has three separate free-trade agreements, with Russia, Kazakhstan and Belarus, and that it hopes that it will be able to get better access to EEU markets, through the unification of the trade regime. This decision is not in contradiction with the SAA, but the EU expects Serbia not to take any steps that would lead to the violation of EU rules." 37 Later, in October Johannes Hahn, Commissioner for European Neighbourhood Policy and Enlargement Negotiations, stated on behalf of the European Commission that "During the screening part of the accession negotiations in spring

${ }^{31}$ Yaroslav Lissovolik, Serbia's FTA with the Eurasian Union: A Window of Opportunity, Valdai Discussion Club, 2 March 2017, http://valdaiclub.com/a/highlights/serbia-fta-with-theeurasian-union/, 1 July 2017.

${ }^{32} \mathrm{Ibid}$.

33 TASS Russian News Agency, Serbia plans to sign free trade zone agreement with Eurasian Economic Union, November 3 2016, http://tass.com/economy/910479, 1 July 2017.

${ }^{34}$ Karanovic \& Nikolic, Serbia To Sign An Agreement With The Eurasian Economic Union, 26 August 2016, https://www.karanovic-nikolic.com/knnews/Pages/2016/08/26/Serbia-to-sign-anAgreement-with-the-Eurasian-Economic-Union.aspx, 2 July 2017.

${ }^{35}$ TASS.

${ }^{36}$ Stabilisation and Association Agreement between the European Communities and their Member States of the One Part, and the Republic of Serbia, of the Other Part, OJ, 2010, L 28/2, Art. 39.1.

${ }^{37}$ ANSAmed, EU: Serbia's agreement with EEU not in violation of of SAA, 6 June 2016, http://www.ansamed.info/ansamed/en/news/nations/serbia/2016/06/06/eu-serbias-agreement-witheeu-not-in-violation-of-saa_e3318d9c-alcf-4ecb-b09e-c018f3763148.html, 2 July 2017. 
2014, Serbia committed to denounce all of its free trade agreements on the day of the accession to the EU. Until then, Serbia can exercise its own trade policy." 38

The issue here relates to the principle of the exclusive competence of the European Union in relation to the Common Commercial Policy (CCP), meaning that in this area that there has been a complete transference by the Member States to the EU of this particular competence. ${ }^{39}$ This principle of exclusive competence was first explicitly articulated as far back as Opinion 1/75 by the European Court of Justice, where it held to the idea of the impossibility of "concurrent powers by the Member States and the Community in this area." ${ }^{40}$ Thus Serbia, though presently free to negotiate a free trade agreement with the EAEU, would have no choice legally but to denounce such an agreement due to European Union law. However, in the meantime, it has a freedom to negotiate such an agreement, if it so wishes.

The leadership of Serbia has not seen any contradiction between its course of the country's European Union integration, and former President Tomislav Nikolic has stated that "We remain consistent in implementing European integration as our foreign policy priorities, but we give full support to other integration processes, too, such as the Eurasian Union." ${ }^{11}$ It has even been proposed that Serbia could act as "a bridge between the EU and the Eurasian Economic Union", allowing the country "to become a window for Russia into the West and for the EU to intensify and strengthen its ties in the East". ${ }^{42}$ However, the extent to which this is possible is open for debate. It may be said with some confidence that there are other factors beyond purely legal considerations when it comes to any possible future agreement between Serbia and the EAEU. Despite affirmations by various European Union officials, due to tensions between the EU and Russia over such issues as Ukraine and the sanctions imposed against the latter, it is not clear as to how positively the former will respond to a signing of a free trade agreement between Serbia and the EAEU. ${ }^{43}$ If countries like Serbia wish to establish truly substantial, stable and long-term relations with the Eurasian Economic Union

${ }^{38}$ European Parliament, Parliamentary questions: Answer given by Mr Hahn on behalf of the Commission, 12 October 2016, http://www.europarl.europa.eu/sides/getAllAnswers.do?reference $=$ E-2016-005020\&language $=$ PT, 4 July 2017.

${ }^{39}$ Paul Craig and and Grainne De Burca, EU Law: Text, Cases, and Materials, Oxford, Fifth Edition, 2011, 311.

40 Opinion 1/75, (Understanding on a Local Cost Standard) [1975] ECR 1355, 1364. Based on this Opinion and subsequent ECJ case-law, the Lisbon Treaty of 2009 incorporated into the EU Treaty structure the principle of exclusive EU competence in the field of CCP. (See Art. 3(1) TFEU).

${ }^{41}$ B92, Serbia consistent in EU bid, backs Eurasian Union, too, August 24 2016, http://www. b92.net/eng/news/politics.php?yyyy=2016\&mm=08\&dd=24\&nav_id=99005, 4 July 2017.

${ }^{42}$ Y. Lissovolik.

${ }^{43}$ Anna Nadibaidze, Will Serbia be able to balance between Russia and the West, Russia Direct, February 17 2017, http://www.russia-direct.org/analysis/will-serbia-be-able-balance-between-russia-and-west, 4 July 2017. 
while also being fully fledged members of the European Union, this can only be in the context of broader agreement and consensus between the EU and EAEU and the overcoming and solving of unresolved issues between both organizations.

As mentioned above, the Eurasian integration project has been seen as part of a greater aim of creating a common great space with the European Union, stretching "From Lisbon to Vladivostok." 44 It must be said that this seems very unlikely at this present moment in time due to the state of relations between Russia and the West. ${ }^{45}$ However, in spite of tensions in recent years, this is an ideal for which support is still expressed at the highest levels. In 2016 President Putin stated that "Along with our Chinese colleagues, we are planning to start official talks on the formation of comprehensive trade and economic partnership in Eurasia with the participation of the European Union states and China." He went on to add that "I expect that this will become one of the first steps toward the formation of a major Eurasian partnership, [...] the "greater Eurasia". ${ }^{46}$ Important voices from within the European Union have also continued to express support for such a project. German Chancellor Angela Merkel in 2016 said that "I hope that Russia would increasingly develop ties with the European economic area, finally resulting in a common economic area from Lisbon to Vladivostok." ${ }^{\prime 7}$ European Commission President Jean-Claude Juncker had also said "I have always found the idea of an integrated trade area linking Lisbon to Vladivostok to be an important and valuable objective." 48 However, at this time these thoughts and aspirations have no real likely path of implementation existing at the present moment due to the present complexity of relationships.

\section{CONCLUSION}

As seen by the statements of the Russian president, it has been explicitly acknowledged that the model of the European Union provides a major part of the inspiration for the Eurasian Economic Union model. Thus, it may in fact be argued

44 Victoria Ivanchenko, Debunking myths about the Eurasian Economic Union, Russia Direct, August 19 2016, http://www.russia-direct.org/opinion/debunking-myths-about-eurasian-economic-union, 4 July 2017.

${ }^{45} \mathrm{Ibid}$

${ }^{46}$ Danilo Elia, The Greater Eurasia, Putin's idea of Europe after Brexit, Eastwest, June 29 2016, http://eastwest.eu/en/opinions/riding-the-russian-rollercoaster/the-greater-eurasia-putin-sidea-of-europe-after-brexit, 6 July 2017.

${ }^{47}$ Sputnik News, From Lisbon to Vladivostok: Merkel Seeks Free Trade Zone Between Russia, EU, 5 June 2016, https://sputniknews.com/politics/201606051040810928-merkel-eu-russia-cooperation/, 6 July 2017.

${ }^{48}$ The Baltic Course, Lithuanian MFA: Juncker's words on EU-Russia ties his personal opinion, not EU's, 20 November 2015, http://www.baltic-course.com/eng/baltic_states/?doc=113180, 6 July 2017. 
that the creation and promotion of this integration project in the Eurasian space is in fact, to a certain extent, an example of the European Union institutional and economic model spreading beyond its own borders, acting as a prototype for integration projects in other parts of the world. As has been argued above, it is debatable as to what extent Serbia can establish truly comprehensive and meaningful relations with the Eurasian Economic Union in the long term beyond symbolism or broad statements in light of the country's European Union accession aspirations. Though the SAA does not technically preclude or prohibit legal agreements such as a free trade zone with third parties like the EAEU, in reality this would be much more difficult to implement, and even if it were achievable, the rules with regards to EU Member States trade agreements and the Common Commercial Policy would preclude a separate agreement between Serbia and the EAEU once the former attains full Member State status of the European Union. As a result, it can be said that in the long term, for countries who are or will be EU Member States and who wish to establish closer relations with the EAEU on a legal basis, the only long term possibility and solution would be the EU as a whole coming to a comprehensive understanding and agreement with the EAEU. In the present environment this does not seem very likely, but as seen above, there are those from within both the EU and EAEU who maintain a desire for a broader and expanded integrative space that would go beyond the borders of their own organizations. 


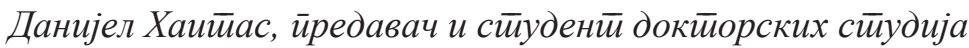
Универзийей у Дебрецину

Правни факулиетеи

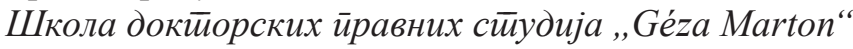

danielhaitas@gmail.com

\section{Преглед Евроазијске економске уније и њеног односа са Србијом}

Сажейак: Поред Евройске уније, у различийим деловима свейа йојавили су се друг̄и рег̄ионални иниеегррациони йројектии. Један значајан иримерак овог̄а јестие Евроазијска економска унија (ЕEУ), која иеежи да реинйегрище бивщи совјетиски иростиор. Ову унију чине следећи чланови: Јерменија, Белорусија, Казахсӣан, Кирг̄истиан и Русија. До одређене мере ЕЕУ налази инсииращију у Евройској унији, иоосмайрајући је као модел који у одређеној мери може да ойонаща и из којег може да учи. ЕЕУ је ойворена за нове чланове, а йражи и йарйнере, йоред осйалог̄ и у Евройи. Један иример овог̄ јестие и Србија, која је йоказала иниеересовање за йойиичсивање сйоразума о слободној йрг̄овини са ЕЕУ. Правно йосмайрано, йо је могууће, јер није забрањено Сйоразумом о стиабилизачији и иридруживағу који је Србија йоййисала. Међуйим, йакав иравач развоја може да има и своје

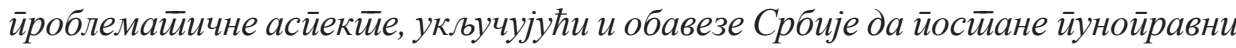
члан Евройске уније и йрироду Заједничке ӣрг̄овинске йолийике ЕУ.

Кључне речи: рег̄ионална иниеег̄рација, Евроазијска економска унија, Евройска унија, Србија, Сйоразум о слободној йрг̄овини.

Датум пријема рада: 11.09.2017. 